\title{
OPETUSHALLINNON HISTORIAA
}

Historiallinen kuva menneisyydestä tarkentuu ja selkiytyy sitä mukaa, kun sen eri aloja tutkitaan ja tuloksia julkaistaan. Tämä koskee myös hallintoa. Osoituksena tästä ovat opetusministeriön historian tähän mennessä ilmestyneet viisi osaa.

Ensimmäinen osa, Keisarillisen Suomen senaatin kirkkopolitiikka 1809-1824, ilmestyi 1979 Tapani Vuorelan väitöskirjana. Sen koh- teena oli varsinaisesti kirkkoinstituutio ja sen toiminnan perustekijät. Kirkon ja koulun läheisen yhteyden vuoksi siinä tarkasteltiin myös koululaitokseen liittyviä asioita, jotka tällöin kuuluivatkin senaatin kansliatoimituskunnalle. Kirkollistoimituskunnalle ne siirrettiin vasta 1841.

Tällöin on siirrytty jo historian toiseen osaan, Taantumuksesta uudistuksiin 1825- 
1868. Osa ilmestyi 1980 niinikään Tapani Vuorelan kirjoittamana. Aikakauden alkuosaa kirjoittaja nimittää " virkavaltaisuuden kukoistuskaudeksi"' ja loppuosaa, vuosia 1856-1868, ajaksi jolloin "uudistuksen tuulet puhaltelivat". Tällaiset tuulet puhaltelivat näinä aikoina monilla muillakin kuin opetustoimen aloilla.

Kolmannen 1985 ilmestyneen osan Kielitaistelusta sortovuosiin 1869-1917 kirjoitti Markku Heikkilä. Uudistuksen tuulet puhaltelevat edelleen. Kirkollistoimituskunnan tehtävät laajenivat koulutoimen alalla, jolloin myös kielija kansallisuuskysymykset saivat aiempaa enemmän huomiota osakseen. Myös tieteen ja taiteen edistäminen liittyi ja vakiintui opetushallinnon tehtäväalaan.

Neljäs osa, Ensimmäisen tasavallan kulttuuripolitiikkaa 1917-1944, aloittaa opetushallinnon historian itsenäisessä Suomessa. Kirjoittaja on Veli-Matti Autio ja ilmestymisvuosi 1986. Se on myös nimensä mukaisesti ensimmäinen opetusministeriön historia. Senaatista tuli näet itsenäisyyden alussa valtioneuvosto sekä kirkollistoimituskunnasta ensin kirkollis- ja opetusasiain toimituskunta ja 1922 opetusministeriö. Sen käsiteltäviksi määrättiin tällöin asiat, jotka koskivat evankelis-luterilaista kirkkoa ja muita uskonnollisia yhdyskuntia, opetustointa, tiedettä, taidetta ja urheilua. Kirkolliset asiat mainitaan luettelossa edelleen ensimmäisinä, vaikka historiassa niiden käsittelyyn on tarvittu vain vajaa neljännes tekstistä.

Uusimpana on syksyllä 1990 ilmestynyt VeliMatti Auloksen ja Markku Heikkilän kirjoittama viides osa, Jälleenrakennuksen ja kasvun kulttuuripolitiikkaa 1945-1965. Se osoittaa ministeriön tehtävän painottuneen entistä enemmän kulttuuripolitiikkaan. Tavoitteeksi mainitaankin kehittää opetusministeriöstä tosiasiallinen kulttuuriministeriö. Parhaillaan kirjoitettavana olevassa kuudennessa osassa voitaneen paremmin kuin vielä nyt arvioida, kuinka tämä tavoite on toteutunut.

Tässä yhteydessä ei ole tarkoitus laajemmin arvioida opetusministeriön historiaa. Suorittamani esittelykin on tarkoitettu huomion kiinnittämiseksi siihen, että opetushallinnon yleishistoria antaa taustan sen piiriin kuuluvien erityisalojen tuntemukselle ja tutkimukselle. Tähän liittyy mielestäni myös se erinomainen seikka, että kunkin osan lopussa on tiiviinä esitetty siihen sisältyvät tutkimustulokset. Niistä saa hyvän yleiskuvan kirkollis- ja opetushallinnosta kunakin aikakautena. Tutkimusosasta voi sitten ammentaa lisätietoa ja tarkennusta haluamistaan asioista.

\section{Vapaa sivistystyö opetushallinnossa}

Varsinaisena tarkoituksena on ollut tarkkailla opetushallinnon historiaa, millaisen "siivun" vapaa sivistystyö siihen muodostaa. Vapaana sivistystyönä on tällöin pidetty toimintaa, jota eri aikoina on nimitetty valistustoiminnaksi, valisI tustyöksi, kansanvalistukseksi, kansansivistykseksi ja lopulta myös aikuiskasvatukseksi.

Kahdessa ensimmäisessä osassa tällaisesta ei ole mainintaa. Tämä ei johdu suinkaan mistään laiminlyönnistä, sillä se vähä mitä kansanvalistukseksi katsottavaa toimintaa tällöin harjoitettiin, tapahtui vapaana kansalaistoimintana ja mieluummin erossa hallinnosta kuin siihen liittyen.

Autonomian ajan loppupuolella, josta historian 3. osa kertoo, alkoi viritä myös sellaista sivistystoimintaa, joka edellytti viranomaisten toimenpiteitä. Syntyi seuroja (esimerkiksi Kansanvalistusseura), joiden tuli saada säännöilleen senaatin vahvistus. Tällaisista ei voi odottaa mainintaa opetushallinnon yleishistoriassa. Vapaata sivistystyötä käsittelevä "siivu" alkaa kansanopistosta 1890-luvun alussa. Kansanopistot tarvitsivat senaatin myöntämän toimiluvan sekä avustuksia toimintaansa varten. Työväenopistoista, jotka niinikään tarvitsivat toimiluvan ja joita myös perustettiin jo autonomian aikana, alkavat maininnat vasta 4 . osassa, jossa käsitellään itsenäisyyden ajan ensimmäisiä vuosikymmeniä.

Itsenäisyyden alussa vapaa sivistystyö käsitettiin erääksi kansalliseksi sivistystehtäväksi ja se alkoi laajeta kaikilla perinteisillä aloilla. Valtiovaltakin tuki sitä aiempaa enemmän, kun venäläinen virkavalta ei asettanut sille esteitä.

Tuen vakiinnuttamiseksi luotiin tällöin lakisääteiset valtionapujärjestelmät kansanopistoja (1925), työväenopistoja (1926) sekä kansankirjastoja (1928) varten. Harkinnanvaraisen valtionavun piiriin jäivät edelleen sivistysjärjestöt sekä luento- ja opintokerhotoiminta. Tätä kehitystä on historian 4. osassa selostettu varsin perusteellisesti. Muuta selostettavaa ei sitten juuri ollutkaan kuin kansanopisto- ja työväenopistolain vähäiset muutokset 1930-luvulla.

Sotien jälkeistä aikaa vuoteen 1965 käsittelevässä historian 5 . osassa osoitetaan vapaassa sivistystyössä tänä aikana olleen kaksi merkittävää vaihetta, toinen alussa ja toinen lopussa. Samalla kun alkoi toiminnan vireytyminen sodanaikaisesta lamasta, myös valtiovallan taholla 
alkoi eri alojen kehittämissuunnittelu. Jo 1937 asetetun kansanopistokomitean mietintö valmistui 1945. Samana vuonna asetettiin kirjastokomitea ja työväenopistokomitea, 1946 opintokerhokomitea sekä 1949 kansankorkeakoulukomitea. Viimeksi mainittua lukuunottamatta muut saivat tehtävänsä päätökseen ennen vuosikymmenen loppua.

Mietinnöissä ehdotettiin myös lainsäädäntötoimia. Vain kansanopistolaki uusittiin 1950 muiden jäädessä odottamaan aikaa parempaa. Vuosikymmen kului ja vasta 1960-luvun alussa uusittiin kirjastolaki (1961), työväenopistolaki (kansalais- ja työväenopistolaiksi 1962) ja säädettiin opintokerholaki (1964).

Miksi 1950-luvulla ei tapahtunut suunniteltua kehittämistoimintaa, on enemmän poliittisessa kuin hallintohistoriassa vastattava kysymys. Viimeksi mainittu kyllä osoittaa, että jokseenkin koko ajan on oltu toimessa varsinkin työväenopistolain uusimiseksi. On pyydetty lausuntoja, laadittu luonnoksia ja jälleen lau- suntoja. Ehkä osaselitys on se, että tänä aikana opetusministeriössä isännöi kymmenkunta ministeriä, joten kukin ehti paneutua vain mielestään tärkeimpien asioiden edistämiseen. Eivätkä vapaan sivistystyön asiat ole yleensä olleet kaikkein tärkeimpiä.

Eivätkä ne ole ottaneet kovin suurta "'siivua" opetusministeriön historiassakaan, mutta kuitenkin kerta kerralta laajemmin. Niihin tarvittiin 3. osassa vain kuusi sivua, 4. osassa jo runsaasti kaksinkertainen määrä (13 sivua) ja 5 . osassa 22 sivua. Sen jälkeen tapahtuneen kehityksen perusteella rohkenee ennustaa, että 6 . osaan tarvitaan jälleen runsaasti enemmän.

KOSTI HUUHKA 